\title{
Pengaruh Harga, Pelayanan, Keragaman Barang dan Kenyamanan Berbelanja terhadap Keputusan Belanja Konsumen di Matahari Department Store Surabaya
}

\author{
*Nur Aini \\ STIA Bayuangga Probolinggo, Indonesia
}

DOI: $10.46821 /$ benchmark.v2i1.225

\begin{abstract}
Abstrak
Studi ini bertujuan untuk menguji dan menganalisis pengaruh harga, pelayanan, keragaman barang, kenyamanan berbelanja konsumen di Department Store Surabaya baik secara parsial maupun secara simultan. Studi ini menggunakan variabel bebas yaitu harga, pelayanan, keragaman barang, kenyamanan berbelanja serta variabel terikat yaitu keputusan belanja konsumen. Dari pembahasan dan pengujian secara simultan maupun secara parsial ke empat variabel bebas yang meliputi : harga, pelayanan, keragaman barang, dan kenyamanan berbelanja berpengaruh secara signifikan terhadap keputusan belanja pada Department Store di Surabaya dengan tingkat $a=5 \%$. Selanjutnya besarnya pengaruh harga, pelayanan, keragaman barang dan kenyamanan berbelanja terhadap keputusan belanja konsumen di Department Store Surabaya sebesar $62,7 \%$ sisanya sebesar $37,3 \%$ dipengaruhi oleh faktor lain yang tidak dibahas dalam model ini.
\end{abstract}

Kata Kunci: Harga, Pelayanan, Keragaman Produk, Kenyamanan, Keputusan Belanja.

\begin{abstract}
This study aimed to test and analyze the influence of price influence, service, equipment of goods, comfort go shopping of Matahari Department Store in Surabaya either parsially and also in simultan. This study used independent variables; they are: of price influence, service, equipment of goods, comfort; and a dependent variable, decision of consumer shopping. From the discussion and the testing in simultan and also parsially to four free variable covering: price, service, equipment of goods, and comfort go shopping having an effect on in significant to decision go shopping of Matahari Department Store in Surabaya with level a= $5 \%$. Here in after level of price influence, service, equipment or goods and comfort go shopping to decision of consumer shopping of Matahari Department Store in Surabaya equal to $62,7 \%$ the rest equal to $37,3 \%$ influenced by other factor un discussed in by this model.
\end{abstract}

Keywords: Price, Service, Product Variability, Comfort, Shopping Decision.

\section{PENDAHULUAN}

Belanja saat ini bukan lagi sekedar sebuah kegiatan untuk memenuhi kebutuhan hidup tetapi juga telah menjadi sebuah gaya hidup. Di era modern saat ini lazim kita dengar shopping atau belanja menjadi hobi dan kesenangan tersendiri. Banyak orang melakukan kegiatan membeli produk atau shopping walaupun mereka tidak memerlukan produk tersebut, namun tidak jarang konsumen mengunjungi tempat belanja hanya untuk membeli kebutuhannya. Belanja adalah salah satu cara untuk memperoleh kebutuhan akan produk dan service tetapi dalam hal ini, motif sosial juga penting.

*Corresponding Author:

Hal: 94-107

Email: na347724@gmail.com 
Dewasa ini, mayoritas masyarakat menjadikan pergi ke mall sebagai gaya hidup (lifestyle). Matahari dijadikan obyek dalam penelitian ini karena selain pergi ke mall yang sudah menjadi gaya hidup (lifestyle) juga Matahari memiliki gerai busana di setiap departement store yang di seluruh mall khususnya di Surabaya. Menurut Kotler (2003), Departement store adalah pengecer yang menjual berbagai lini produk, misalnya pakaian, peralatan rumah tangga. Salah satu departement store terkemuka di Indonesia adalah Matahari. Matahari pertama kali berdiri pada tahun 1958 di pasar baru Jakarta. Matahari menjadi pioneer sebagai departement store di Indonesia tahun 1972. Penghargaan yang pernah diraih oleh Matahari Dept store antara lain: Indonesian most admired company (IMAC) 2006 dari Indonesian retailer association pun pernah di raihnya, selama tiga tahun berturut turut menjadi top retailer di Indonesia (www.matahari.co.id).

Persaingan yang semakin ketat khususnya untuk bisnis ritel, dimana banyak produsen yang terlibat dalam pemenuhan kebutuhan dan keinginaan konsumen, menyebabkan setiap perusahaan ritel harus menempatkan orientasi kepuasan pelanggan sebagai tujuan utama dan diyakini sebagai kunci utama untuk memenangkan persaingan adalah memberikan nilai dan kepuasan kepada pelanggan melalui penyampaian produk dan jasa dengan harga bersaing.

Kepuasan menurut Jhon dan Michael (1998) pelanggan mengalami salah satu dari tingkat kepuasan yang umum, kalau kinerja di bawah harapan pelanggan akan kecewa, kalau kinerja sesuai dengan harapan pelanggan puas, kalau melebihi harapan pelanggan sangat puas atau gembira.

Kepuasan menurut Kotler (2000:36) kepuasan adalah tingkat perasaan seseorang setelah membandingkan kinerja (hasil) yang dia rasakan dengan harapannya. Pada umumnya harapan dari pelanggan merupakan perkiraan/keyakianan pelanggan tentang apa yang diterimanya bila mereka membeli atau mengkonsumsi suatu produk. Kepuasan ini mendatangkan keuntungan karena biaya mendapatkan pelanggan baru lima kali lebih tinggi daripada mempertahankan yang sudah ada.

Philip Kotler (2005:220-225), mengemukakan bahwa keputusan terpenting pengecer yang berhubungan langsung dengan tingkat kepuasaan konsumen adalah :

a. Keragaman produk (Product assortment)

b. Layanan dan atmosfer toko

c. Keputusan harga,

d. Keputusan Promosi,

e. Keputusan tempat (lokasi)

Semakin meningkatnya kebutuhan manusia dalam memenuhi kebutuhan hidup sehari-hari yang didapatkan melalui kegiatan berbelanja di departement store memiliki tujuan untuk mendapatkan kepuasan tersendiri atas aktivitas yang dilaksanakan konsumen. Hal- hal yang akan ditawarkan yang notabene bukan hanya dalam bentuk barang harus memiliki kelebihan-kelebihan khusus yang bersifat positif dibandingkan dengan penawaran usaha ritel lainnya, maka pelanggan tetap setia. Dalam mempertahankan pelanggan, perusahaan harus dapat memberikan kepuasan yang maksimal dalam memuaskan pelanggannya. Adapun kepuasan pelanggan dapat terjadi apabila harapan benar-benar terwujud demikian pula sebaliknya, jika pelanggan merasa puas, maka mereka akan kembali membeli produk kita dan membicarakan hal tersebut kepada orang lain secara menguntungkan. 
Saat ini beberapa departement store telah melaksanakan strategi bauran pemasaran eceran tanpa mengetahui puas atau tidaknya konsumen terhadap hal-hal yang ditawarkan dan tidak pula mengetahui sejauh mana tingkat kepuasan konsumen terhadap strategi yang dilaksanakan tersebut. Dalam hal ini kepuasan bukan hanya milik para konsumen saja melainkan perusahaan juga ikut puas terhadap hal-hal yang ditawarkan. Dengan puasnya konsumen terhadap strategi yang ditawarkan, perusahaan bisa terus menjaga prestasi tersebut atau bahkan terus mengembangkan strategi bauran pemasaran eceran dengan inovasi-inovasi yang berdasarkan dari masukan-masukan para konsumen. Masalah penelitian yang menjadi fokus peneliti adalah untuk mengetahui sejauh mana faktor keragaman produk (product assortment), layanan, harga, kenyamanan dapat menentukan keputusan belanja konsumen di Matahari Department Store Surabaya, sehingga dapat memberikan nilai tambah dan dapat memberikan kebutuhan informasi yang mencerminkan kesinambungan produk dan dapat memenuhi kebutuhan perusahaan dalam meningkatkan kualitas segala hal yang ditawarkan perusahaan, jumlah pelanggan dan jumlah pelanggan yang sudah ada.

Berdasarkan latar belakang tersebut peneliti mencoba untuk mengadakan penelitian dengan mengambil topik pengaruh harga, pelayanan, kelengkapan barang dan kenyamanan berbelanja terhadap keputusan belanja konsumen di Matahari Department Store Surabaya.

\section{TINJAUAN PUSTAKA}

\section{Pengertian Perilaku Konsumen}

Kotler dan Amstrong (2016), mendefinisikan potongan harga sebagai pengurangan Perilaku konsumen (consumer behavior) adalah kegiatan-kegiatan individu yang secara langsung terlibat dalam mendapatkan dan mempergunakan barang dan jasa, termasuk didalamnya proses pengambilan keputusan pada persiapan dan penentuan kegiatankegiatan tersebut. Analisis pasar konsumen dalam hubungan dengan perilaku konsumen dimulai dengan meneliti hal-hal tersebut. Dengan mengetahui hal-hal tersebut di atas, maka akan diketahui kesempatan baru yang berasal dari terpenuhinya kebutuhan.

\section{Teori Perilaku Konsumen}

Pemahaman terbadap perilaku konsumen dalam melakukan pembelian diketahuinya perilaku konsumen dalam pasar, maka perusahaan dapat menentukan kebutuhan dan keinginan pasar serta dapat memberikan kepuasan dengan lebih efektif.

Konsep pemasaran menggunakan perspektif dari luar ke dalam. Artinya bahwa, konsep ini dimulai dengan pemasaran yang terdefinisikan dengan baik, memfokuskan pada kebutuhan pelanggan, pengkoordinasian semua kegiatan yang akan berpijak pada konsep dan di atas, maka pengetahuan tentang kebutuhan dan keinginan konsumen atas pasar sasaran perlu mendapat perhatian dari para manager pemasaran. Hal ini disebabkan karena kebutuhan adalah suatu keadaan dimana terdapat perasaan kekurangan akan kepuasan tertentu, sedangkan keinginan adalah dorongan-dorongan akan pemuasan tertentu dari kebutuhan yang lebih dalam (Kotler, 1994:7). Untuk mengetahui mengapa konsumen memilih produk, merek, penjual, waktu pembelian, dan jumlah pembelian tertentu, maka diperlukan studi tentang sikap konsumen.

a. Siapa yang ada dipasar konsumen?

b. Apa yang dibeli konsumen? 
c. Kapan konsumen membeli ?

d. Bagaimana konsumen membeli ?

Kemudian mengidentifikasikannya untuk mengadakan segmentasi pasar, merupakan salah satu tugas penting manager pemasaran. Ha1 ini disebabkan karena dengan dan efisiennya (Kot1er, 1994:18) penyusunan program pemasaran seperti ini sesuai dengan salah satu falsafah pemasaran yaitu konsep pemasaran (Pawitra, 1993:4) mempengaruhi pelanggan, dan menghasilkan keuntungan melalui penciptaan kepuasan konsumen. Jadi konsep pemasaran berpijak pada empat pilar utama yaitu fokus pada pasar, orientasi pelanggan, pemasaran yang terkoordinasi, dan kepuasan.

Model perilaku pembelian menunjukkan bahwa sikap pembelian konsumen muncul sebagai respon terhadap rangsangan yang diterima. Rangsangan itu berasal dari luar dirinya yaitu rangsangan pemasaran dan rangsangan lingkungan. Rangsangan pemasaran meliputi atribut- atribut produk yang diturunkan oleh pemasar kepada konsumen yang biasanya dikelompokkan ke dalam bauran pemasaran (produk, harga, tempat dan promosi), sedangkan rangsangan lingkungan meliputi : lingkungan ekonomi, teknologi, politik dan sosial-budaya.

Rangsangan lingkungan umumnya tidak mudah untuk dikendalikan oleh pemasar. Pemasar lebih mudah mempengaruhi sikap konsumen melalui rangsangan pemasaran dari pada rangsangan lingkungan. Walaupun demikian, pemasar tetap perlu mengetahui kondisi lingkungan agar mampu mempengaruhi sikap konsumen dengan lebih efektif dan efisien. Pemasar perlu memahami bagaimana latar belakang seorang pembeli (ciri-ciri pembeli) dapat mempengaruhi perilaku pembeliannya dan bagaimana pembeli melewati proses pembuatan keputusannya untuk membuat pilihan pembelian. Latar belakang pembeli dapat dilihat dari faktor-faktor : budaya, sosial, politik dan psikografi.

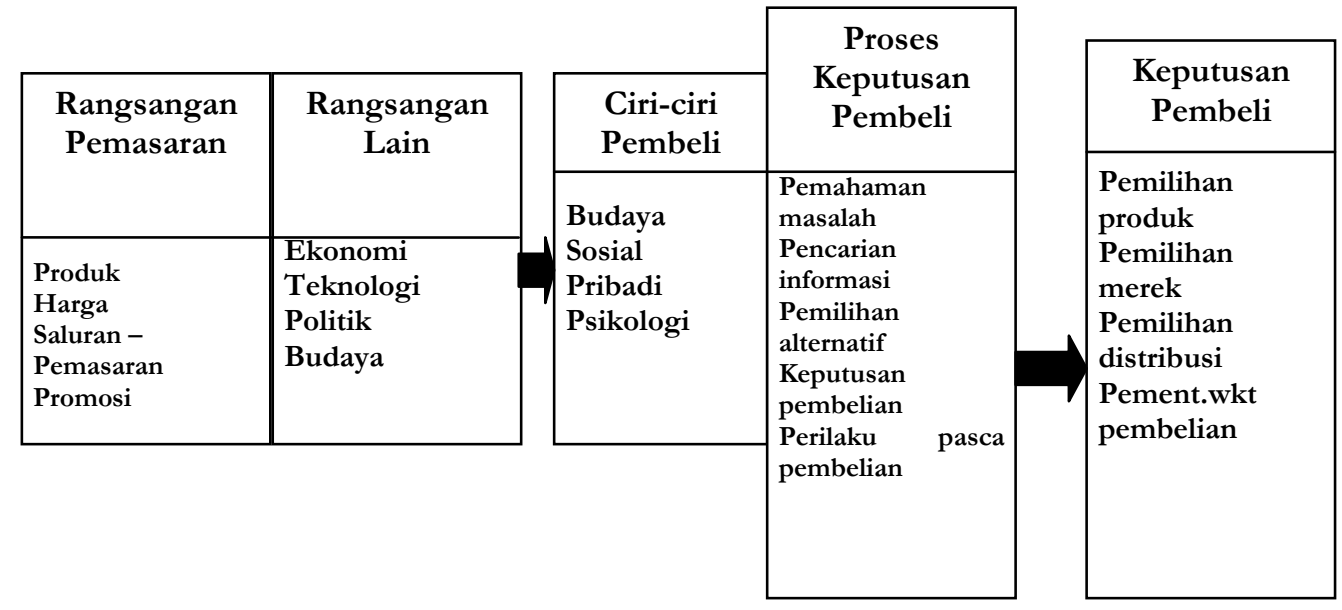

Sumber : Kotler (1994:174)

Gambar 1 Model Perilaku Pembelian 


\begin{tabular}{|c|c|c|c|c|}
\hline \multirow[t]{2}{*}{ Budaya } & & & & \\
\hline & \multirow{2}{*}{$\begin{array}{l}\text { Kelompok } \\
\text { Sosial }\end{array}$} & & & \\
\hline \multirow{4}{*}{$\begin{array}{l}\text { Sub } \\
\text { Kebudayaan }\end{array}$} & & Pribadi & & \\
\hline & \multirow{2}{*}{$\begin{array}{l}\text { Kelompok } \\
\text { acuan }\end{array}$} & \multirow{2}{*}{$\begin{array}{l}\text { Umur \& tahap } \\
\text { siklus hidup. } \\
\text { Pekerjaan situasi } \\
\text { ekonomi } \\
\text { Gaya hidup } \\
\text { Kepribadian dan } \\
\text { konsep diri }\end{array}$} & Psikologis & \multirow[b]{2}{*}{ Pembeli } \\
\hline & & & $\begin{array}{l}\text { Motivasi } \\
\text { Persepsi } \\
\text { Pengetahuan } \\
\text { Keyakinan } \\
\text { dan sikap }\end{array}$ & \\
\hline & & & & \\
\hline
\end{tabular}

Sumber : Kotler \& Amstrong (2001:196)

\section{Gambar 2}

\section{Faktor-faktor yang Mempengaruhi Perilaku}

Sikap konsumen akan mempengaruhi pilihannya dalam membeli, dimana seseorang mempunyai sikap terhadap segala sesuatu, misalnya : agama, politik, pakaian, makanan, dan lain-lain. Sikap menempatkan seseorang dalam kerangka berpikir, menyukai atau tidak menyukai, menghampiri, atau menjual. Menurut Azwar (1988:24) ada beberapa faktor yang mempengaruhi pembentukan sikap yaitu : pengalaman pribadi, kebudayaan, orang lain yang dianggap penting, media massa, institusi atau lembaga pendidikan dan lembaga agama serta faktor emosi dalam diri individu. Hal tersebut menunjukkan bahwa sikap konsumen bisa diubah. Dua cara lain yang bisa dilakukan pemasar untuk mempengaruhi seseorang untuk membeli produk atau merek yaitu : menyesuaikan atribut-atribut produknya dengan sikap konsumen yang telah ada, atau dengan mengubah sikap konsumen. Pilihan manapun dilakukan tentunya didasarkan pada biaya yang dikeluarkan untuk setiap alternatif.

\section{Pengertian Sikap Konsumen}

Menurut Krech dan Crutch field (1984:152), sikap adalah suatu organisasi yang abadi tentang motivasi, emosi, persepsi, dan proses kognitif mengenai beberapa aspek lingkungannya. Menurut Fishbein \& Aizein (1975:6), sikap merupakan suatu kecenderungan yang terpelajari dalam mernberikan respon menguntungkan atau tidak menguntungkan secara konsisten mengenai obyek tertentu. Sedangkan menurut Loudon dan Bitta (1993:423), sikap rnerupakan penilaian positif atau negatif, menyenangkan atau tidak menyenangkan, setuju atau tidak setuju dari perasaan seseorang terhadap Suatu obyek. Namun selanjutnya Fishbein (1993:422) menyatakan bahwa lebih dari 100 definisi tentang sikap, dengan diam maka belum ada kesepakatan yang baru tentang definisi sikap. Menurut Loudon dan Bitta (1993:5), konsumen adalah siapapun sebagai pemakai. 


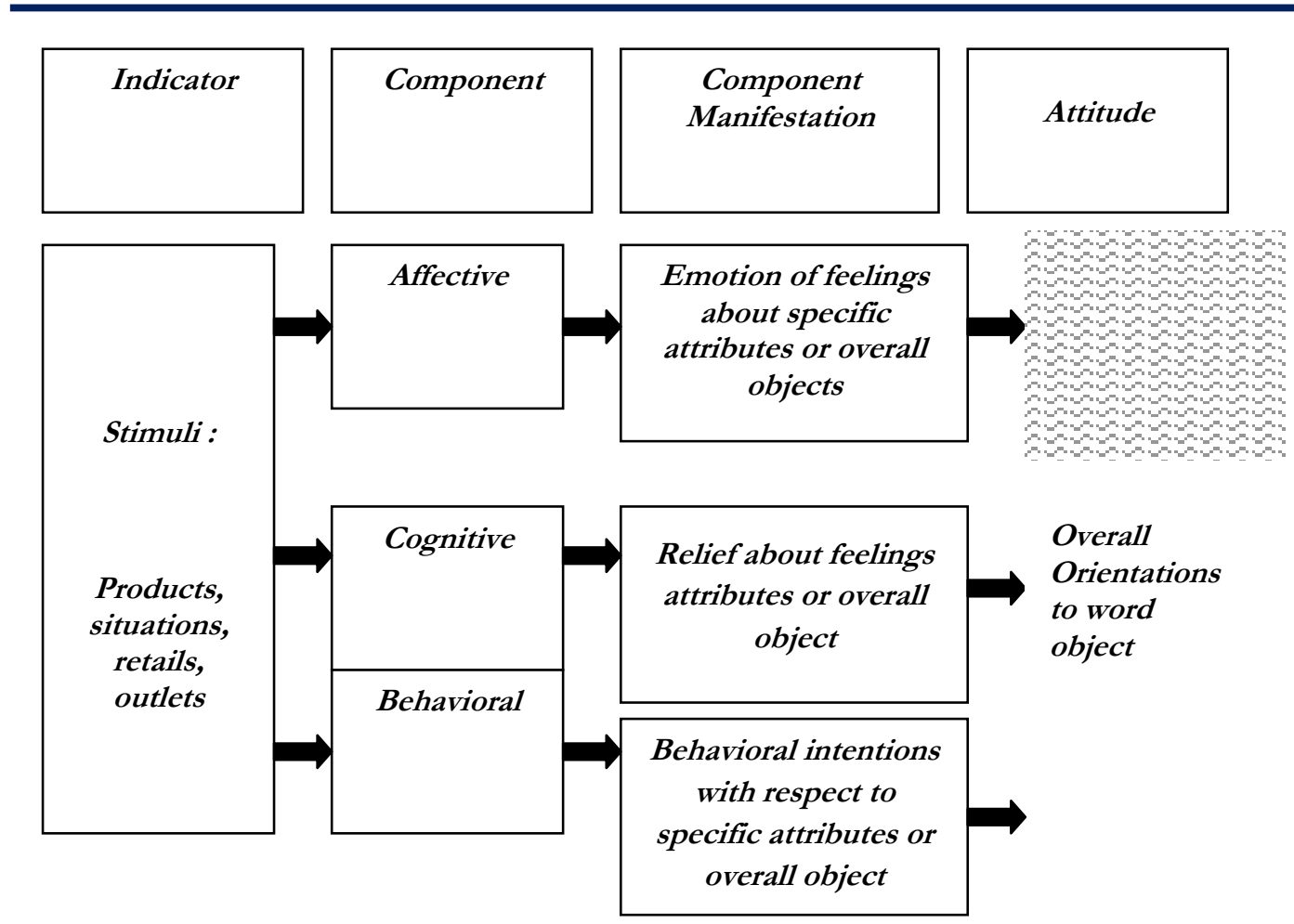

Sumber : Hawkins, et. Al (1992: 350)

\section{Gambar 3}

\section{Komponen-komponen Sikap dan Perwujudannya}

\section{Komponen-komponen Sikap}

Sikap seseorang terhadap suatu obyeK dibentuk oleh tiga komponen utama. Diagrarn 3 berikut rnengilustrasikan tentang tiga komponen sikap yaitu: afektif, kognitif dan psikomotorik (perilaku).

Komponen afektif merupakan perasaan atau reaksi emosi seseorang tentang suatu obyek. Obyek tersebut berupa atribut produk yaitu ciri-ciri atau sifat-sifat produk atau merek. Apakah merek yang ada baik atau buruk? Apakah diinginkan ? Apakah disukainya ? Komponen kognitif, mencakup suatu keyakinan dan pengetahuan tentang suatu obyek. Apakah produk tersebut mahal harganya? Apakah produk tersebut cocok? Komponen ketiga merupakan komponen behavioral atau komponen yang berkaitan dengan soal psikomotor atau perilaku. Komponen behavioral merefleksikan perilakuperilaku yang direncanakan dan aktual terhadap obyek yang bersangkutan. Komponen tersebut merupakan sebuah predisposisi terhadap tindakan.

Komponen sikap manakah yang terpenting dalam situasi pembelian? Menurut Winardi (1991: 138), bobot komponen-komponen sikap terhadap produk berkaitan dengan situasi yang dihadapi pembeli dan tipe pembeli. Jadi dalam hal ini komponen behavioral merupakan komponen terpenting. Pembeli organisatoris dalam melakukan pembelian produk, perlu melakukan studi tentang produk yang diperlukan organisasinya, sehingga komponen kognitifnya lebih menonjol dibandingkan komponen sikap lainnya. 
Pengukuran Komponen Sikap dan Perilaku Pembelian

Permasalahan mendasar dalam pengukuran sikap konsumen adalah kemungkinan tidak adanya kesesuaian antara sikap dengan perilaku. Sejauh mana suatu pengukuran sikap sesuai atau cocok dengan perilaku akan bergantung kepada seberapa baik pengukuran tersebut menangkap empat elemen perilaku yakni : elemen tindakan, target, waktu dan konteks (Jaccard, et.al., 1977:817). Pengukuran sikap menggambarkan elemen tindakan secara akurat. Pengukuran sikap yang lebih akurat, targetnya harus lebih spesifik. Selanjutnya elemen waktu berfokus pada kerangka waktu dimana perilaku diharapkan terjadi. Berbeda dengan tiga elemen diatas, maka elemen konteks mengacu pada tempat dimana perilaku diharapkan terjadi. Untuk itu harus jelas tempatnya dimana, karena ada kemungkinan perbedaan tempat bisa berpengaruh terhadap kualitas atribut produknya. Sikap agar sesuai dengan perilaku, maka elemen-elemen tersebut harus diperhatikan dalam pengukuran sikap. Pengukuran sikap dapat dibagi berdasarkan komponenkomponen yaitu: kognitif, afektif, dan behavior.

\section{Proses Pengambilan Keputusan Untuk Membeli}

Setelah mempertimbangan yang ada pada dirinya maka konsumen akan melakukan proses pengambilan keputusan untuk membeli atau tidak membeli. Proses tersebut merupakan suatu pendekatan penyalesaian masalah yang meliputi beberapa tahap yang dimulai dari jarak sebelum faktor pembelian. Tahap-tahap tersebut adalah:

\section{Menganalisa kebutuhan dan keinginan}

Menganalisa kebutuhan dan keinginan ini ditujukan terutama untuk mengetahui adanya keingian dan kebutuhan yang belum terpenuhi atau terumuskan jika kebutuhan itu diketahui, maka konsumen akan segera memahami kebutuhan yang belum terpenuhi dan atau masih tertunda kebutuhannya, serta kebutuhan yang samasama harus segera dipenuhi. Jadi dalam tahap inilah proses pembelian mulai dilakukan.

\section{Pencarian informasi}

Pencarian informasi dapat bersifat aktif dan bersifat pasif, internal maupun eksternal. Pencarian informasi yang bersifat aktif, dapat berupa kunjungan kebeberapa departement store untuk membuat perbandingan harga dan kualitas produk, sedangkan pencarian informasi pasif, mungkin dengan membaca suatu iklan tanpa mempunyai tujuan khusus dalam pikirannya tentang gambaran produk yang diinginkan. Pencarian informasi intern tentang sumber pembelian dapat berasal dari media masa dan informasi dari sumber-sumber kegiatan pemasaran perusahan.

\section{Penilaian dan seleksi terhadap alternatif pembelian}

Tahap ini meliputi dua tahap, yaitu: penetapan tujuan pembelian dari penilaian serta mengadakan seleksi terhadap alternatif pembelian berdasarkan tujuan pembeliannya, tujuan pembelian dari konsumen tidak selalu sama, tergantung jenis produk dan kebutuhannya. Ada konsumen yang mempunyai tujuan pembelian sekedar untuk memenuhi jangka pendek. Setelah tujuan pembelian ditetapkan, konsumen perlu mengidentifikasikan alternatif pembelian tersebut tidak dapat dipisahkan dari sumber-sumber yang dimiliki atas dasar tujuan pembelian. 


\section{Keputusan untuk membeli}

Keputusan untuk membeli disini merupakan proses dalam pembelian yang nyata. Jadi setelah tahap-tahap dimuka dilakukan maka konsumen harus mengambil keputusan membeli atau tidak, bila konsumen memutuskan untuk membeli, konsumen akan mempunyai serangkaian keputusan yang harus diambil menyangkut jenis produk, merek, penjualan, kualitas, waktu pembelian dan cara membayarnya. Setiap perusahaan dapat mengusahakan untuk menyederhankan pengambilan keputusan yang dilakukan oleh konsumen, karena banyak orang yang mengalami kesulitan dalam mengambil keputusan. Untuk memasarkan dengan cara yang lebih baik, perusahaan perlu mengetahui beberapa jawaban pertanyaan yang menyangkut perilaku konsumen dalam keputusan pembeliannya.

\section{Perilaku sesudah pembelian}

Semua tahap yang ada dalam proses pembelian sampai tahap kelima adalah bersifat kooperatif. Bagi perusahaan, perasaan dan perilaku sesudah pembelian juga sangat penting, dimana perilaku mereka juga sangat mempengaruhi ucapan-ucapan pembelian pada pihak lain tentang produk perusahaan tersebut. Ada kemungkinan bahwa pembelian yang memiliki ketidak sesuaian sesudah melakukan pembelian karena harganya terlalu mahal, atau mungkin tidak sesuai dengan keinginan atau gambaran sebelumnya. Untuk perusahaan dapat bertindak dengan menentukan segisegi tertentu atau servis tertentu dari produknya.

\section{METODE PENELITIAN}

\section{Populasi dan Sampel}

Populasi dalam penelitian ini yaitu konsumen yang berbelanja di Matahari Department Store Surabaya. Oleh karena berbagai keterbatasan waktu, tenaga dan biaya, maka sampel yang akan diambil dalam jumlah tertentu.

Mutu suatu penelitian tidak semata-mata ditentukan oleh kokohnya dasar-dasar teori, rancangan penelitian, serta mutu pelaksanaan dan pengolahannya (Soeratno dan Arsyad, 1999:34).

Karena yang diteliti adalah sebagian dari populasi maka cara pengambilan data menggunakan teknik sampling yang merupakan wakil dari yang akan diteliti, hal ini dilakukan karena akan mengeneralisasikan hasil dari penelitian (Arikunto, 1998:42).

Teknik Sampling yang digunakan adalah purposive sampling yaitu penelitian hanya ditujukan kepada konsumen yang berbelanja di Matahari Department Store Surabaya. Purposive sampling adalah teknik-teknik penentuan sampel dengan pertimbangan dari si peneliti (Sugiono, 1999:51).

Sampel yang dipilih adalah individu yang menurut pertimbangan peneliti dapat mendukung penelitian (Soeratno dan Arsyad, 1999:38). Dalam penyebaran angket, peneliti menggunakan teknik sampel acak (random sample) maksudnya yaitu setiap anggota dari populasi mempunyai kesempatan yang sama untuk dimasukkan sebagai sampel.

\section{Sumber Data dan Teknik Pengumpulan Data}

Dalam penelitian ini, pengumpulan data yang akan dilakukan dengan menggunakan kuisioner yang akan disebarkan kepada responden yang dipilih sebagai sampel dan 
diambil dengan menggunakan pendekatan purposive sampling. Adapun data yang digunakan dalam penelitian ini adalah:

\section{Data Primer}

Data primer atau data tangan pertama ada1ah data yang diperoleh langsung dari subyek penelitian dengan menggunakan alat pengukur atau alat pengambilan data subyek langsung pada subyek sebagai sumber informasi yang dicari (Azwar, 1998:91).

\section{Data Sekunder}

Data sekunder atau data tangan kedua adalah data yang diperoleh dari pihak lain, tidak langsung oleh peneliti dari subyek penelitiannnya (Azwar, 1998:91). Untuk mendapatkan data ini maka digunakan cara sebagai berikut, kuisioner yaitu pengumpulan data dengan cara menggunakan daftar pertanyaan yang telah disusun oleh peneliti yang berupa angket yang ditujukan pada responden. Wawancara adalah data dikumpulkan melalui tanya jawab langsung dengan responden di lapangan.

\section{HASIL ANALISIS DAN PEMBAHASAN}

\section{Uji Asumsi Regresi}

\section{Analisis Regresi Linier Berganda}

Untuk mengetahui pengaruh harga, pelayanan, kelengkapan barang dan kenyamanan terhadap keputusan belanja konsumen maka digunakan analisis regresi linier berganda. berdasarkan hasil perhitungan yang telah dilakukan dengan program statistik SPSS diperoleh hasil sebagai berikuut (Tabel 1).

Selanjutnya untuk membuktikan hipotesis yang diajukan dalam penelitian ini dilakukan uji $\mathrm{F}$ dan uji t. Uji F digunakan untuk menguji pengaruh variabel bebas secara simultan sedangkan uji t digunakan untuk menguji pengaruh variabel bebas secara parsial.

\section{Tabel 1}

\section{Hasil Analisis Regresi Linier Berganda}

\begin{tabular}{lllll}
\hline Variabel & Koefisien Regresi & Standar Error & t hitung & Sig. \\
\hline Kualitas layanan & 0,240 & 0,051 & 4,764 & 0,000 \\
Harga & 0,119 & 0,047 & 2,393 & 0,016 \\
keragaman barang & 0,135 & 0,051 & 2,507 & 0,011 \\
Kenyamanan berbelanja & 0,161 & 0,075 & 2,161 & 0,031 \\
Konstanta $=0,262$ & & & & \\
$\mathrm{R}$ & $=0,792$ & & & \\
$\mathrm{R}^{2}$ & $=0,627$ & & & \\
$\mathrm{~F}$ hitung & $=31,483$ & & & \\
$\mathrm{n}$ & $=100$ & & & \\
\hline
\end{tabular}

Sumber: Data primer yang diolah 
Uji F (Pengujian Secara Simultan)

Untuk menguji pengaruh variabel harga, pelayanan, keragaman barang dan kenyamanan secara simultan terhadap variabel keputusan belanja konsumen maka digunakan uji F. Adapun langkah-langkah pengujiannya sebagai berikut :

\section{Menentukan hipotesis :}

Ho : $\mathrm{b}_{1}, \mathrm{~b}_{2}, \mathrm{~b}_{3}, \mathrm{~b}_{4}=0$, artinya harga, pelayanan, keragaman barang dan kenyamanan secara simultan tidak berpengaruh terhadap keputusan belanja konsumen.

$\mathrm{Ha}: \mathrm{b}_{1}, \mathrm{~b}_{2}, \mathrm{~b}_{3}, \mathrm{~b}_{4}=0$, artinya harga, pelayanan, keragaman barang dan kenyamanan secara simultan berpengaruh terhadap keputusan belanja konsumen.

Dengan menggunakan taraf signifikansi $95 \%(\alpha=0,05)$ dan derajat kebebasan $(\mathrm{df})=(\mathrm{n}$ $\mathrm{k}) ;(\mathrm{k}-1)=(75) ;(4)$ diperoleh $\mathrm{F}$ tabel sebesar 2,494.

\section{Kriteria Pengujian}

Ho diterima apabila $\mathrm{F}$ hitung $\leq 2,494$

Ho ditolak apabila F hitung $>2,494$

Hasil perhitungan diperoleh $\mathrm{F}$ hitung $=31,483$

Hasil perhitungan menunjukkan nilai $\mathrm{F}$ hitung $>\mathrm{F}$ tabel $(31,483>2,494)$ atau mempunyai tingkat signifikansi sebesar 0,000 (kurang dari 0,05) sehingga hipotesis nol (Ho) ditolak dan hipotesis alternatif $(\mathrm{Ha})$ diterima. Dengan diterimanya Ha berarti harga pelayanan, keragaman barang dan kenyamanan secara simultan berpengaruh terhadap keputusan belanja konsumen di Matahari Department Store Surabaya.

\section{Uji t (Pengujian Secara Parsial)}

Untuk membuktikan pengaruh variabel-variabel bebas terhadap parsial/individu terhadap variabel terikat maka digunakan uji t. Dalam pengujian ini digunakan taraf signifikansi $(\alpha)=5 \%$, derajat kebebasan $(\mathrm{df})=(\mathrm{n}-\mathrm{k})=75$ dengan pengujian dua sisi diperoleh $\mathrm{t}$ tabel $=1,992$. Adapun kriteria pengujiannya sebagai berikut :

Ho diterima jika $-1,992 \leq \mathrm{t}$ hitung $\leq 1,992$.

Ho ditolak jika thitung $<-1,992$ atau t hitung $>1,992$.

\section{Pengujian Pengaruh Harga terhadap Keputusan Belanja Konsumen Menentukan Hipotesis}

Ho $: b_{1}=0$, artinya harga tidak berpengaruh terhadap keputusan belanja konsumen.

$\mathrm{Ha}: \mathrm{b}_{1} \neq 0, \quad$ artinya harga berpengaruh terhadap keputusan belanja konsumen.

Hasil Perhitungan Diperoleh t Hitung $=4,764$

Daerah Penerimaan Ho dan Daerah Penolakan Ho untuk Uji Koefisien Regresi Harga. Hasil perhitungan menunjukkan bahwa t hitung $>$ t tabel $(4,764>1,992)$ atau mempunyai tingkat signifikansi sebesar 0,000 (kurang dari 0,05) sehingga hipotesis nol (Ho) ditolak dan hipotesis alternatif $(\mathrm{Ha})$

\section{Uji Pengaruh Pelayanan Terhadap Keputusan Belanja Konsumen Menentukan Hipotesis}

Ho $: b_{2}=0$, artinya pelayanan tidak berpengaruh terhadap keputusan belanja konsumen diterima. 
$\mathrm{Ha}: \mathrm{b}_{2} \neq 0$, artinya pelayanan berpengaruh signifikan terhadap keputusan belanja konsumen

Dengan diterimanya $\mathrm{Ha}$ berarti harga berpengaruh secara signifikan terhadap keputusan belanja konsumen di Matahari Department Store Surabaya, dan pengaruhnya adalah positif, sehingga apabila harga produk yang ditawarkan oleh di Matahari Department Store Surabaya semakin baik maka keputusan belanja konsumen juga akan mengalami peningkatan. Hasil Perhitungan Diperoleh $\mathrm{t}$ Hitung $=2,393$. Hasil perhitungan menunjukkan bahwa t hitung $>\mathrm{t}$ tabel $(2,393>1,992)$ atau mempunyai tingkat signifikansi sebesar 0,000 (kurang dari 0,05) sehingga hipotesis nol (Ho) ditolak dan hipotesis alternatif $(\mathrm{Ha})$ diterima. Dengan diterimanya $\mathrm{Ha}$ berarti pelayanan berpengaruh secara signifikan terhadap keputusan belanja konsumen dan pengaruhnya adalah positif, sehingga apabila pelayanan yang diberikan oleh di Matahari Department Store Surabaya, belanja konsumen juga akan meningkat.

\section{Uji Pengaruh Keragaman Barang terhadap Keputusan Belanja Konsumen Menentukan Hipotesis}

Ho $: b_{3}=0$, artinya keragaman barang tidak berpengaruh terhadap keputusan belanja konsumen diterima.

$\mathrm{Ha}: \mathrm{b}_{3}=0$, artinya keragaman barang berpengaruh terhadap keputusan belanja konsumen diterima.

Hasil Perhitungan Diperoleh t Hitung $=2,507$. Hasil perhitungan menunjukkan bahwa t hitung $>\mathrm{t}$ tabel $(2,507>1,992)$ atau mempunyai tingkat signifikansi sebesar 0,000 (kurang dari 0,05) sehingga hipotesis nol (Ho) ditolak dan hipotesis alternatif $(\mathrm{Ha})$ diterima. Dengan diterimanya $\mathrm{Ha}$ berarti kelengkapan barang berpengaruh secara signifikan terhadap keputusan belanja konsumen dan pengaruhnya adalah positif, sehingga apabila barang yang disediakan oleh di Matahari Department Store Surabaya semakin beragam maka keputusan belanja konsumen juga akan meningkat.

\section{Uji Pengaruh Kenyamanan terhadap Keputusan Belanja Konsumen Menentukan Hipotesis}

Ho: $\mathrm{b}_{4}=0$, artinya kenyamanan tidak berpengaruh terhadap keputusan belanja konsumen diterima.

Ho $: b_{4}=0$, artinya kenyamanan berpengaruh terhadap keputusan belanja konsumen diterima.

Hasil Perhitungan diperoleh $t$ hitung $=2,161$. Hasil perhitungan menunjukkan bahwa $\mathrm{t}$ hitung $>\mathrm{t}$ tabel $(2,161>1,992)$ atau mempunyai tingkat signifikansi sebesar 0,000 (kurang dari 0,05) sehingga hipotesis nol (Ho) ditolak dan hipotesis alternatif $(\mathrm{Ha})$ diterima. Dengan diterimanya $\mathrm{Ha}$ berarti kelengkapan barang berpengaruh secara signifikan terhadap keputusan belanja konsumen dan pengaruhnya adalah positif, sehingga apabila barang yang disediakan oleh di Matahari Department Store Surabaya semakin beragam maka keputusan belanja konsumen juga akan meningkat.

\section{SIMPULAN DAN SARAN}

Dari hasil penelitian dan analisis data dapat disimpulkan sebagai berikut, berdasarkan hasil uji Anova dengan menggunakan uji F secara simultan menunjukkan bahwa faktor harga, pelayanan, keragaman barang dan kenyamanan secara simultan berpengaruh 
signifikan terhadap keputusan belanja konsumen. Hal ini ditunjukkan oleh nilai $\mathrm{F}$ hitung $(31,483) 1$ ebih besar dari nilai $\mathrm{F}$ tabel $(2,494)$. Hasil pengujian secara parsial (uji t) dengan tingkat signifikasi alpha $=5 \%$, menunjukkan bahwa harga, pelayanan, kelengkapan barang dan kenyamanan secara parsial berpengaruh signifikan terhadap keputusan belanja konsumen dan pengaruhnya adalah positif sehingga apabila faktor harga, pelayanan, keragaman barang dan kenyamanan semakin baik maka keputusan belanja konsumen juga akan meningkat. Ini ditunjukkan oleh nilai t hitung untuk faktor harga (2,393), faktor pelayanan (4,764), faktor keragaman barang (2,507) dan faktor kenyamanan $(2,161)$ lebih besar dari nilai t tabel $(1,992)$. Hubungan variabel harga, pelayanan, keragaman barang dan kenyamanan terhadap variabel keputusan belanja konsumen sangat kuat hal ini ditunjukkan koefisien korelasi $\mathrm{r}=0792$. Kontribusi variabel harga, pelayanan, keragaman barang dan kenyamanan terhadap variabel keputusan belanja konsumen) sebesar 62,7\% sisanya sebesar 37,3\% disebabkan oleh faktor lain yang tidak dibahas dalam model ini, misalnya daya beli masyarakat, selera konsumen, kondisi perekonomian, tingkat persaingan dan sebagainya. Berdasarkan hasil penelitian, analisis data serta kesimpulan yang telah diuraikan maka dapat diberikan saran-saran sebagai berikut, pengaruh faktor harga, pelayanan, kelengkapan barang dan kenyamanan terhadap keputusan belanja konsumen cukup besar yakni 62,7\%, sekalipun demikian selain faktor-faktor tersebut perlu dipertimbangkan dalam mengambil keputusan dalam rangka untuk meningkat omset penjualan misalnya : kondisi persaingan karena akhir-akhir ini banyak bermunculan departement store modern sebagai pesaing, dengan kondisi seperti itu diharapkan dapat meningkatkan kinerja agar tetap dapat eksis di era persaingan yang semakin kompetitif ini. Dalam hal kenyamanan berbelanja perlu mendapatkan perhatian yang lebih besar lagi dari pengelola departement store misalnya: tempat yang lebih luas dan mudah dijangkau oleh konsumen. Disamping itu loker tempat penyimpanan dan penitipan barang-barang konsumen dapat ditingkatkan lagi keamanannya jangan sampai barang konsumen hilang atau tertukar dengan milik orang lain agar konsumen merasa nyaman dan aman berbelanja sambil menikmati iringan musik bahkan kalau perlu bisa disediakan cafe sederhana dan tempat bermain anak-anak. Sehubungan dengan variabel harga yang mempengaruhi keputusan pembelian, konsumen, hendaknya pihak manajemen mampu mempertahankan harga yang saat ini berlaku di pasaran, serta memperhatikan harga yang kompetitif dengan produk lain yang sejenis. Selama hal tersebut pihak manajemen juga harus mampu menjaga kualitas terhadap produk yang ditawarkan, kelengkapan barang dan kenyamanan berbelanja karena ini juga mempengaruhi keputusan belanja konsumen. Pihak manajemen senantiasa melakukan inovasi dan perbaikan kinerja diantaranya: keragaman jenis produk, penataan produk yang dipajang, suasana internal, merek barang yang ditawarkan, komparasi harga dengan pesaing, serta program kupon berhadiah yang lebih menarik setiap periodik. Perlu adanya satu riset yang dilakukan secara berkala sehingga dapat diketahui apa yang perlu serta yang diinginkan konsumen.

\section{DAFTAR PUSTAKA}

\footnotetext{
Algifari, 1997, "Statistika Induktif untuk Ekonomi dan Bisnis" , UPP AMP YKPN, Yogyakarta.
} 
Augusty Ferdinand. 2000. "Manajemen Pemasaran : Sebuah Pendekatan Strategik". Program Management Diponegoro University Surabaya.

Andrew, J.C., 1989. The Dimensionality of Beliefs Toward Advertising General. Journal Advertising. Vol. 18. h. 26-35

Azwar Saifuddin. (2003). Skala Psikologi. Yogyakarta: Pustaka Pelajar.

Azwar, Saifuddin. 2003. Reliabilitas dan Validitas. Sigma Alpha: Yogyakarta

Buchari Alma. (2004). Manajemen, Pemasaran dan Pemasaran Jasa. Bandung: Penerbit Alfabeta.

Craven, Davids W. 1995. "Pemasaran Strategi", Jilid 1-2 (Edisi Terjemahan). Erlangga.

Djarwanto, 1995. "Statistik Non Parametrik ", Bandung, Alumni.

Doyle. Peter and John Saunders. 1995. "The Lead of Marketing Decision". "Journal of Marketing Research". Edition 22 ${ }^{\text {th }}$ (february). P. 54.65.

Darmadi Durianto, dkk. (2001). Strategi Menaklukkan Pasar Melalui Riset Ekuitas dan Perilaku Merek. Jakarta : PT. Gramedia Pustaka Utama.

Djaslim Saladin. (2003). Manajemen Pemasaran Analisis, Perencanaan, Pelaksanaan dan Pengendalian. Bandung : CV. Linda Karya.

Freddy Rangkuti. (2002). The Power of Brands. Jakarta: Gramedia Pustaka Utama.

Ghozali, Imam. 2001. "Aplikasi Analisis Multivariate Dengan Program SPSS". Badan Penerbit UNDIP: Surabaya.

Gujarati. Damodar, 1995, "Basic Econometrics”. McGraw-Hill International Editions: New York.

Handoko, Hani T., 1987. Manajemen Personalia dan Sumber Daya Manusia. Liberty : Yogyakarta.

Harun Al Rasyid. (1994). Teknik Penarikan Sampel dan Penyusunan Skala. Program Studi Ilmu Sosial-Bidang Kajian Utama Sosiologi Antropologi Program Pasca Sarjana Universitas Padjajaran: Bandung

Hermawan Kertajaya. (2004). Hermawan Kartajaya on Brand. Bandung : Penerbit Mizan. 
Husein Umar. (2002). Metode Penelitian Aplikasi dalam Pemasaran. Jakarta: PT. Gramedia Pustaka Utama.

Istijanto. (2005). Aplikasi Praktis Riset Pemasaran. Jakarta: Gramedia Pustaka Utama.

Koppale K, Preveen and Lehman Donald R. 1995. 'The Effects of Advertised Quality on Expectation about New Product Quality. Journal of Marketing Research. Vol. XIV, March.

Kotler, Philip, 1995, "Manajemen Pemasaran - Analisis, Perencanaan, Implementasi dan Pengendalian", Jilid 1 - 2, Edisi Indonesia, Salemba Empat, Jakarta.

Kerlinger, Fred N. (1990). Asas-asas Penelitian Behavioral. Edisi terjemahan Yogyakarta. Gadjah Mada University Press.

Knapp, Duane E. (2001). The Brand Mind Set. (Alih bahasa: Drs. Sisnahudi, MBA). Yogyakarta: Penerbit Andi.

Kotler, Philip. (2004). Dasar-dasar Riset Pemasaran Jilid 1. Edisi Bahasa Indonesia. Jakarta: PT. Indeks.

Mela, Carl F., Sunil Gupta dan Donald R. Lehmann. 1997. The Long Term Impact of Promotion and Advertising on Sunsumer Brand Choice, Journal of Marketing Research. Vol XXXIV. P. 248-261.

Masri Singarimbun dan Sofian Effendi. (1995). Metode Penelitian Survei. Jakarta: LP3ES.

Moh. Nazir. (1999). Metode Penelitian. Edisi Kedua. Jakarta : Ghalia Indonesia.

Singarimbun, Masri dan Sofian Effendi, "Metode Penelitian Survei", Edisi Revisi, Jakarta, Penerbit LP3ES.

Singgih Santoso, 2000, Buku Latiban SPSS Statistik Parametrik, PT. Elex Media Komputindo Kelompok Gramedia, Jakarta.

Singgih Santoso. (2004). Mengatasi Berbagai Masalah Statistik Dengan SPSS 11.5. PT. Gramedia Pustaka: Jakarta.

Usman, Husaini. 1995. Pengantar Statistik. Jakarta: PT. Bumi Aksara. 